\title{
K FILOZOFICKÝM VÝCHODISKÁM SÚČASNÝCH MODELOV ZDRAVOTNEJ STAROSTLIVOSTI
}

\author{
EVA SMOLKOVÁ, Filozofický ústav Slovenskej akadémie vied, Bratislava, SR
}

SMOLKOVÁ, E.: On the Philosophical Bases of Current Models of Health Care FILOZOFIA, 74, 2019, No 8, pp. $637-651$

\begin{abstract}
Most of us understand health care as a system in which certain values and moral standards must apply. We will try to grasp different types of health care systems, the way they work and, above all, specify how the systems differ from one another. We will investigate the issue of the access to health care and we will show how the theoretical and practical approaches to health issues intersect and influence each other. We will try to explain why this occurs on the background of socio-political theories and concepts that currently resonate in this area. Different theoretical bases as well as different approaches to health care require systematization and specification of criteria of differences, so that we can orientate ourselves in these issues and know the basic approaches that are present in contemporary health care. The point is, however, to show how moral approaches and moral judgments affect the methods and methodologies that are used in relation to these issues and how this may impact on the practical delivery of health care.
\end{abstract}

Keywords: Equality - Justice - Solidarity - Health care systems - Values

\section{Úvod}

Pojem zdravotníctvo slúži na označenie systému zdravotnej starostlivosti a chápeme ho ako vytvorený a aplikovaný systém na poskytovanie zdravotnej starostlivosti. Problematiku etiky v zdravotníctve zvyčajne vzt’ahujeme na fungovanie celého systému, avšak filozofia sa väčšinou nezaoberá tvorbou normatívnych kritérií vo vzt'ahu k pacientovi v systéme zdravotnej starostlivosti, ale konkrétnymi problémami jednotlivých profesií, najmä lekárskej a ošetrovatel'skej starostlivosti ${ }^{1}$ (Held 2015, 87 - 88).

\footnotetext{
${ }^{1}$ Jestvujú tri základné názorové prúdy, ktoré sa v danej oblasti profilovali a fungujú. V rámci prvého je etika v zdravotníctve systémom profesijných prístupov tých profesií, ktoré v zdravotníctve pôsobia, a teda netreba robit’ nijakú konkrétnu analýzu pojmov, ked’že nám odpovede na morálne problémy v oblasti zdravotníctva môžu poskytnút' jednotlivé profesijné etiky, akými sú: medicínska etika, etika v ošetrovatel'stve, podnikatel'ská etika a d’alšie, ktoré vstupujú do procesov morálneho rozhodovania v danej oblasti. Druhý profiluje medicínsku etiku ako zdravotnícku etiku. V jeho rámci sa presadzuje názor, že hodnoty a normatívne kritériá obsiahnuté v medicínskej etike plne pokrývajú potreby etiky $\mathrm{v}$ zdravotníctve, a preto nie je potrebné a ani vhodné implementovat' d’alšie prístupy a normatívne kritériá. Tretí prístup začleňuje etiku v zdravotníctve do systému bioetiky a vníma ju ako jednu z oblastí, v rámci ktorých sa vytvárajú morálne vzt’ahy k životu a špecifikujú sa tie postoje, ktoré platia pri posudzovaní humánnych problémov. V jej rámci sa často argumentuje, že v práve
} 
Existuje nespočetné množstvo publikácií o medicínskej etike a problémoch, ktoré sa $\mathrm{v}$ jej rámci riešia, čo je pochopitel'né, lebo zodpovednost' za liečbu vždy nesie lekár. Zodpovednost' v systéme zdravotnej starostlivosti sa však prenáša aj na iné, najmä ziskové subjekty, ktoré pôsobia $\mathrm{v}$ zdravotníctve, pričom ich ciele a nástroje v procese zdravotnej starostlivosti sú diametrálne odlišné od tých, ktoré profilujú medicínsku etiku. Klúčcové je teda to, aké hodnoty sú v systéme zdravotnej starostlivosti nastavené, aké reálne fungujú a ktoré sú $\mathrm{z}$ legislatívneho a morálneho hl'adiska záväzné.

Systematické skúmanie systému a morálnych princípov platných pre celý systém zdravotnej starostlivosti vel'mi často absentuje napriek tomu, že ak aj dôjde k zlyhaniu v procese poskytovania zdravotnej starostlivosti, hovorí sa o etike $\mathrm{v}$ zdravotníctve a o problémoch súvisiacich $\mathrm{s}$ implementáciou morálnych kritérií $\mathrm{v}$ jeho rámci. Problém sa umocňuje tým, že vo svete fungujú dva základné typy systémov poskytovania zdravotnej starostlivosti a je dôležité uchopit’ rozdiely medzi nimi, pretože sú významné nielen pre fungovanie zdravotníctva, ale aj pre morálnu filozofiu. Systémy zdravotnej starostlivosti možno kategorizovat' ako sociálno-liberálny vytvorený na princípe solidarity, a libertariánsky, opierajúci sa o radikálny individualizmus. ${ }^{2}$ Ich morálne charakteristiky a implementačné kritériá boli nakoncipované pri ich tvorbe a uplatňujú sa v praxi, hoci problém je zložitejší, pretože systémy zdravotnej starostlivosti vo svojej „čistej“ podobe prakticky nefungujú. Jednotlivé prístupy sa navzájom kombinujú často až do takej miery, že nemožno identifikovat', či fungovanie systému determinujú sociálne alebo liberálne prístupy, a zároveň je problém pomenovat', ktoré hodnoty v nich platia. Ciel’om analýzy bude identifikácia hodnotových rozdielov a medzi sociálno-liberálnym a libertariánskym systémom zdravotnej starostlivosti.

bioetika umožňuje uchopit' problémy širšie a systematickejšie, vnímat' celý kontext problematiky nielen smerom k výkonu lekárskej praxe, ale aj k výskumu a implementácii nových techník, technológií, liečiv a postupov v zdravotníctve ako celku. Bioetika podl'a toho umožňuje zaoberat' sa morálnymi aspektmi takých vied, akými sú biológia, farmakológia, biofyzika, chémia a iné. K problematike pozri aj Smolková, E.: Etika v zdravotnictve. Filozofický ústav SAV, Bratislava 2014, 15 -26.

${ }^{2}$ Súčasnú diskusiu o najvhodnejšej interpretácii spravodlivosti výrazne ovplyvnili najmä dve práce: Rawlsova Teória spravodlivosti (1971) a Nozickova Anarchia, štát a utópia (1974). Rawlsovo dielo možno označit' za základ súčasného sociálneho liberalizmu, resp. egalitarizmu, ktorý sa opiera o kantovský predpoklad rovnosti a slobody jednotlivcov. Týka sa pravidiel distribúcie a redistribúcie tak základných foriem dobra, ako aj slobôd. Róbert Nozick je považovaný za najvýznamnejšieho predstavitel'a libertarianizmu. Rozdiel medzi Rawlsovými a Nozickovými názormi tkvie najmä v tom, že zatial' čo Rawls stavia svoju teóriu na sociálnej kooperácii jednotlivcov v základnej štruktúre spoločnosti, kde sa distribúcia sociálnych statkov zabezpečuje prostredníctvom inštitúcií, Nozick uprednostňuje kritérium radikálneho individualizmu, kde sa v konečnom dôsledku každý musí spoliehat' len sám na seba a svoje schopnosti. Z tohto hl'adiska je Rawlsova teória sociálneho liberalizmu protipólom individualistickej verzie liberalizmu R. Nozicka. 


\section{Právo na zdravotnú starostlivost'?}

Z filozofického, etického, ale najmä axiologického hl'adiska sú dôležité hodnoty, ktoré systém kreovali a ktoré v ňom dlhodobo fungujú, a zároveň, ako sme naznačili, legislatívne a morálne kritériá platné pre jednotlivé profesie. Rozsah štúdie neumožňuje zaoberat'sa otázkami platnosti a fungovania morálnych noriem a princípov v zdravotníctve, ani vznikom morálnych noriem vo vzt’ahu k zdraviu. Preto sa sústredíme na morálnu teóriu v otázke prístupu $\mathrm{k}$ zdraviu, ktorá je podmienená najmä konceptom l’udských práv a slobôd. Napriek tomu, že právo na zdravotnú starostlivost' v l’udských právach nie je zakotvené a nepatrí medzi základné práva a slobody, koncept starostlivosti, ktorý je jeho súčast'ou, sa stal determinujúcim činitel'om, ktorý podmienil proces vytvárania sociálnych práv, ktoré sú akoby rozšírením l'udských práv na úrovni jednotlivých štátov, presnejšie tých, ktoré takéto práva do svojich ústav zakotvili. ${ }^{3}$

Starostlivost' vo vzt'ahu k jednotlivcovi sa odvíja od toho, či je zdravotná starostlivost' z hl'adiska človeka, občana štátu, nárokovatel'ná alebo nie a či občan má právo na zdravotnú starostlivost' a môže ho aj reálne uplatnit' a využívat'. Zaistenie starostlivosti, a to tak sociálnej, ako aj zdravotnej, sa v jednotlivých krajinách líši v závislosti od toho, či hovoríme o sociálnom štáte a o akom konkrétnom modeli sociálneho štátu. ${ }^{4}$ Pojem sociálny štát zahŕňa celý rad prvkov sociálnej politiky, ktorých ciel’om je reagovat' na sociálne riziká a eliminovat' sociálne dôsledky trhového mechanizmu. K základným prvkom sociálnej politiky patria sociálna pomoc, sociálna podpora, dôchodkové a zdravotné poistenie, zdravotná politika, politika zamestnanosti, rodinná a bytová politika, ako aj systém vzdelávania (Palovičová 2013, 15). Zdravotné poistenie je jedným z nástrojov sociálnej politiky, a aj prostriedkom zmierňovania vplyvov trhu na sociálne slabších. Systém zdravotnej starostlivosti je postavený na princípoch sociálneho štátu a je dôsledkom kreovania sociálnych tradícií v európskom prostredí. Je determinovaný princípom solidarity, čo značí, že na zdravotnú starostlivost' má nárok každý, bez ohl'adu na to, do akej miery ju jeho zdravotný stav vyžaduje či akou sumou do systému prispieva, alebo či zaňho prispieva štát. Solidárny systém zdravotnej starostlivosti je preferovaným modelom v krajinách Európskej únie a má formu zdravotného poistenia.

Starostlivost' ako determinujúci princíp predpokladá akceptáciu individuálnych potrieb a rešpekt voči človeku. Princíp starostlivosti v zdravotníctve sa týka zdravia

\footnotetext{
${ }^{3} \mathrm{~K}$ sociálnym právam patria právo na zdravotnú starostlivost', právo na sociálne zabezpečenie a právo na zdravé životné prostredie.

${ }^{4} \mathrm{~V}$ teórii sa zvyčajne pracuje so štyrmi základnými modelmi sociálneho štátu. Štáty môžeme v súlade s členením G. Esping-Andersena rozdelit' na tie s liberálnym (Británia, USA, Írsko), konzervatívnym (korporativistickým; Nemecko, Francúzsko, Rakúsko), sociálnodemokratickým (univerzalistickým; Švédsko, Dánsko, Nórsko) a rudimentárnym (južanským; Taliansko, Španielsko, Grécko) modelom. K rozdielom medzi nimi pozri Esping-Andersen, G. (1990): The Three Worlds of Welfare Capitalism. Cambridge: Polity Press.
} 
ako takého a potreby či povinnosti starat' sa oň (Sedová, Palovičová 2018, 31), ${ }^{5}$ čím je zároveň povedané, že povinnost' starat' sa o zdravie je neprenosná. Primárne sa týka človeka ako indivídua, a až následne, v prípade potreby, ochorenia, úrazu alebo inej udalosti, zdravotníctva ako systému, presnejšie povedané konkrétnych profesií v zdravotníctve.

Ako sme sa pokúsili naznačit', systémy zdravotnej starostlivosti sa koncipujú na základe toho, či a do akej miery štát akceptuje l'udské práva, a na základe toho, či je alebo nie je právo na ochranu zdravia súčastou ústavných práv. Právo na zdravotnú starostlivost' je zakotvené aj v Ústave Slovenskej republiky. ${ }^{6}$ Niektorí teoretici uvádzajú pojem „uznaných“ práv v štáte, to je však tematika rýdzo legislatívna. Napriek tomu, že základom sú morálne normy nonmaleficiencia, benefícia, autonómia a justícia, až na základe legislatívnych princípov sa kreujú konkrétne možnosti a podmienky poskytovania zdravotnej starostlivosti v štáte. Kompetencie štátov sú pri vytváraní kritérií zdravotnej starostlivosti nezastupitel'né, ale krajiny, ktoré sú zoskupené v Európskej únii, sa pri jej vzniku dohodli, že budú preferovat' taký systém zdravotnej starostlivosti, ktorý je postavený na princípe solidarity. Súčast’ou európskych dohovorov je totiž vol'ný pohyb osôb a zjednotenie systémov sa odvodzuje práve od potreby poskytnút' zdravotnú starostlivost' občanom štátov Európskej únie v ktoromkolvvek členskom štáte. ${ }^{7}$

Zatial' čo v každej krajine Európskej únie je vytvorený systém zdravotnej starostlivosti - hoci sme si vedomí odlišností a rôznej kvality poskytovania zdravotnej starostlivosti v členských štátoch -, zdravotná starostlivost' nie je štandardom vo všetkých krajinách sveta. Všeobecne prijímaný systém zdravotnej starostlivosti teda nejestvuje. Sú krajiny, v ktorých žiadny systém nie je, a aj také, v ktorých sú zdravotnícke a sociálne služby úzko prepojené. Odlišné charakteristiky zdravotníckych služieb vychádzajú aj z toho, čo sa za zdravotnú starostlivost' pokladá a čo nie a či je starostlivost' o zdravie privátnou vecou, teda vecou osobnej zodpovednosti každého človeka za svoje zdravie, alebo nie. Doteraz sme v súvislosti s krajinami Európskej únie hovorili o tom, že zaistenie zdravotnej starostlivosti je verejný záujem, a teda aj zdravotníctvo má podobu verejnej služby (public healt). Od toho sa totiž odvíja, ako budeme zdravotníctvo

\footnotetext{
${ }^{5}$ Autorky T. Sedová a Z. Palovičová hovoria o základnom katalógu l'udských práv, ku ktorým patria tzv. substitučné práva - život, výživa, bývanie, voda, primeraná životná úroveň.

${ }^{6}$ Ústava SR sa o tomto práve zmieňuje v piatom oddiele prvej hlavy. V článku 40 sa hovorí: „Každý má právo na ochranu zdravia. Na základe zdravotného poistenia majú občania právo na bezplatnú zdravotnú starostlivost' a na zdravotnícke pomôcky za podmienok, ktoré ustanoví zákon.“

7 Tento systém sa nepretržite dotvára, ale vstup do Európskej únie bol a je podmienený vytvorením takého systému zdravotnej starostlivosti, ktorý akceptuje smernice EÚ v oblasti zdravotníctva. Krajiny, čo taký systém nemajú, ho musia vytvorit' a prispôsobit' sa štandardom, ktoré zoskupenie preferuje.
} 
posudzovat' a kto a do akej miery sa bude podiel'at' na financovaní zdravotníctva ako systému a jeho výkonov v záujme zdravia občanov.

Pojem zdravie však nie je jednoduché vymedzit'. Zdravie je stav organizmu, ktorý určujú medicínske kritériá, a tie sú v zásade funkčnými kritériami. Medicína posudzuje fungovanie organizmu a funkčné hl'adisko je pre medicínu najjednoduchšie uchopitel'né a pragmatické. Zdravie je podl'a toho určované limitmi medzi hraničnými hodnotami, je optimálnym funkčným stavom živého systému v jeho aktívnych a reaktívnych životných prejavoch. Podl'a definície Svetovej zdravotníckej organizácie je ,zdravie stav úplnej telesnej, duševnej a sociálnej pohody, ${ }^{8}$ a nielen neprítomnost' choroby “ ${ }^{\circ}{ }^{9}$ Táto definícia je jednou z najkritizovanejších, lebo podl'a nej nemožno určit', kto je zdravý človek. Na základe medicínskych kritérií však možno povedat', kedy je človek chorý, ako aj to, že zdravie je opakom choroby. Zdravie je podl'a toho možné pokladat' za formu existencie organizmu, ktorá sa vylučuje s chorobou, čo v praxi znamená, že zdravie je definované tým, čím nie je. Posudzovat' zdravie z filozofického hl'adiska však takýmto spôsobom nemožno, preto filozofická literatúra akceptuje medicínske vymedzenie pojmu a venuje sa najmä tej jeho časti, v ktorej sa hovorí o sociálnej pohode a sociálnych väzbách.

Pojem zdravotníctvo vnímame najmä cez jeho funkcie. Ak máme však uchopit', čo je zdravotná starostlivost', narazíme na argument, že nemožno jednoznačne vymedzit' pojem starostlivost'. Starostlivost' sa dá uchopit' len vo vzt'ahu ku konkrétnym výkonom, teda v procese distribúcie zdravotnej starostlivosti. Požiadavka spravodlivosti v súvislosti s distribúciou zdravotnej starostlivosti podl’a potrieb je však ideálom. Ciel'om systému zdravotnej starostlivosti je poskytnút' kvalitnú službu v súlade s modernými poznatkami vo vedeckých a medicínskych odboroch. Zdravotníctvo má však aj d'alšie dve funkcie. Prvou je zabezpečenie prevencie pred určitými ochoreniami a druhou vytvorenie krízových opatrení v prípade hrozby epidémií. Ide o určenie princípov štátnej zdravotnej politiky.

Morálne kritériá hrajú významnú rolu v procese kreovania systému a podmieňujú aj to, ako má fungovat', ako sa budú riešit' otázky kvality života, ochrany života a zdravia obyvatel'stva. Legislatívne kritériá a stratégia premietnutá do štátnej zdravotnej politiky podmieňujú, aké potreby a do akej miery systém má a môže uspokojovat'. V epistemologickom zmysle slova je ciel'om pochopit', čo vyžaduje morálka starostlivosti, pretože ,koncepcia morálky vybudovanej na predobraze nezávislého, autonómneho a racionálneho jedinca prehliada závislost’ na druhých“ (Held 2015, 23).

\footnotetext{
${ }^{8}$ Niektoré preklady používajú termín sociálne blaho.

9 Ústava Svetovej zdravotníckej organizácie (WHO). Dostupné na: https://www.who.int/govenance/eb/ who_constitution_en.pdf
} 
Ochrana života a zdravia, kvality života a nastavenie toho, či a do akej miery sa to bude vzt'ahovat' na všetkých občanov štátu, sa tvorí priebežne a závisí od morálnych východísk a navrhovaných metód a metodík riešenia konkrétnych situácií. Spôsoby riešenia i prístupy $\mathrm{k}$ otázke zdravia a následne zdravotnej starostlivosti ${ }^{10}$ sú v rôznych krajinách vel'mi diferencované, aj ked' určité systematické znaky sa dajú uchopit’ a popísat'. Podl'a čoho sa teda možno orientovat? Ako sme už naznačili, v zásade je to možné na základe toho, či a aké typy sociálnych práv sú v právnom systéme danej krajiny ukotvené, konkrétne či krajina garantuje právo na zdravotnú starostlivost'. ${ }^{11}$ Od tohto sa totiž odvíjajú základné prístupy a spôsoby riešenia otázok zdravia a zdravotnej starostlivosti v štáte.

\section{Systémy zdravotnej starostlivosti}

Zaoberat' sa fungujúcimi systémami zdravotnej starostlivosti znamená pomenovat' tie, ktoré je možné uchopit' zo systematického hladiska, nevykazujú znaky chaotickosti a ich zásadné črty sa nemenia vždy so zmenou politiky alebo politickej orientácie. ${ }^{12}$ Ciel'om je predstavit' čitatel'ovi, aké systémy zdravotníckej starostlivosti vo svete jestvujú, na akých princípoch fungujú a aké morálne princípy v ich rámci platia. Problematika systémov zdravotnej starostlivosti je posudzovaná z hladiska hodnoty, akú zdravie predstavuje. Zásadné rozlíšenie je totiž dané tým, či je zdravie chápané ako individuálna, alebo ako spoločenská hodnota (Palovičová 2012, 76). To je základný identifikačný činitel', od ktorého sa odvíja, či a aký systém zdravotnej starostlivosti v danej krajine funguje. Potrebu starat' sa o zdravie si však nemusia osvojovat' vždy len indivíduum alebo štát ako celok, týka sa aj iných subjektov, napríklad zamestnávatel'ov, mimovládnych organizácií, profesijných združení, štátnych inštitúcií či charitatívnych organizácií iných krajín a, samozrejme, inštitúcií s nadnárodnou pôsobnost'ou, ktoré sa zaoberajú otázkami zdravia a zdravotníctva.

\footnotetext{
${ }^{10}$ WHO chápe zdravotnú starostlivost' nielen ako starostlivost' o prinavrátenie zdravia, ale aj ako starostlivost' o udržanie zdravia. WHO používa nasledujúcu kategorizáciu, podl'a ktorej zdravotná starostlivost' zahíňa prevenciu, dispenzarizáciu, diagnostiku, liečbu, biomedicínsky výskum, ošetrovatel'skú starostlivost' a pôrodnú asistenciu.

${ }^{11}$ Právo na ochranu zdravia bolo zakotvené v Ústave Československej republiky. Zákon o péči o zdraví lidu (20/1966 Sb.) bol prijatý ako základný právny predpis zdravotníckeho práva v Československu. Vymedzoval povinnosti štátu, zdravotníckych zariadení i uživatel’ov zdravotníckych služieb a zásady zdravotnej starostlivosti. Od roku 1966 až do roku 1990 nebol ani raz novelizovaný. Novelizácie boli v nástupníckych štátoch odlišné. V Slovenskej republike je toto právo zakotvené v piatom oddiele prvej hlavy Ústavy SR č. 40. V Slovenskej republike bol prijatý nový Zákon č. 277/1994 Zb. o zdravotnej starostlivosti a d'alší v roku 2004 - Zákon č. 576/2004 Z. z. o zdravotnej starostlivosti, službách súvisiacich s poskytovaním zdravotnej starostlivosti a o zmene a doplnení niektorých zákonov.

12 Podobne ako v iných oblastiach, aj v zdravotníctve jestvujú rôzne originálne experimenty. Tie však fungujú len na základe určitých politických atribútov viazaných na danú krajinu, v ktorej platia.
} 
Hoci právo na zdravotnú starostlivost' nemá podobu kantovského kategorického imperatívu, je v súlade s deontologickými východiskami, ktoré v systéme dlhodobo fungujú. Znamená to, že systém má v štáte určené funkcie a plní roly, ktoré sa vzt’ahujú na všetkých občanov, určité sociálne skupiny i jednotlivcov. Jedným z jeho hlavných ciel'ov je zabezpečenie celoplošnej preventívnej starostlivosti a tvorba podmienok na ochranu zdravia ako spoločenskej hodnoty. V zásade je starostlivost' takmer vždy individuálna, aj napriek tomu, že jestvujú určité „univerzálne“ kritériá. Akceptácia individuálnych potrieb a požiadaviek sa buduje na základe rešpektu, teda uznania a akceptácie človeka a priznaním práva rozhodovat' o sebe. $\mathrm{V}$ súvislosti s hodnotou, akou je spravodlivost', sa vo filozofickej komunite diskutuje o koncepte spravodlivosti ako férovosti. Rovnaký prístup k zdravotnej starostlivosti bol koncipovaný na základe Rawlsovej teórie spravodlivosti, tá sa však v posledných rokoch stala predmetom kritiky najmä preto, že neponúka reálnu rovnost' príležitostí, a to najmä v prípade špeciálnych potrieb, akými sú rôzne druhy znevýhodnení (Palovičová 2012, 76). Autori, ktorí sa zaoberajú typológiou systémov zdravotnej starostlivosti (Gladkij 2003, 30 a n.) hovoria o dvoch až piatich modeloch. Nebudeme ich uvádzat', pretože niektoré z nich analyzujú len špecifiká konkrétnych modelov, iní ako modelový príklad vnímajú aj neexistenciu akéhokol'vek systému. Ak analyzujeme filozofické východiská, ktoré ideovo profilujú súčasné systémy poskytovania zdravotnej starostlivosti, tak môžeme hovorit' o dvoch modeloch fungovania a organizovania systému zdravotnej starostlivosti na úrovni štátu libertariánskom a sociálno-liberálnom. Predstavíme obidva modely fungovania a organizovania systému zdravotnej starostlivosti na úrovni štátu

Ak sa zdravie pokladá za individuálnu hodnotu, starostlivost' o zdravie sa stáva privátnou záležitost’ou. V takomto prípade vzniká libetariánsky model zdravotnej starostlivosti. V ňom je zdravotná starostlivost’ tovarom, ktorý sa nakupuje a predáva na základe princípov ponuky a dopytu. Princípy liberálneho individualizmu, ako argumentuje R. Nozick (Nozick 1997, 122) sú vo svojej podstate spravodlivejšie, pretože tovary a služby sú majetkom tých, ktorí ich vyprodukovali. Princípy trhovej ekonomiky navyše fungujú selektívne a zo systému vyradia tých, ktorí poskytujú nekvalitné tovary služby. Posudzovat' zdravie ako tovar však nie je zd'aleka také jednoduché, ako by sa na prvý pohl'ad mohlo zdat'. Na zdravie sa totiž vzt'ahuje princíp osobnej, teda individuálnej zodpovednosti. Podl’a toho je každý človek zodpovedný za seba a svoje zdravie. Problém však nastáva vtedy, ked' človek za svoj zdravotný stav zodpovedný nie je, sám si ho nespôsobil, alebo zdravotnú starostlivost' potrebuje už od narodenia. Zdravotná odkázanost' je problém, ktorý liberálny individualizmus ignoruje. Z hl'adiska štátu sú potom otázky zdravotného stavu obyvatel'stva nepodstatné, neriešia sa ako prioritné problémy. Zdravotná starostlivost' nemá povahu verejnej služby, ale služby individuálnej. Napriek tomu štát nemôže, vzhl'adom na iné l'udské práva a slobody, ignorovat' 
potreby obyvatel'stva ako celku a „stavat' sa chrbtom“ k nemajetným a odkázaným bez zretel'a na to, či ide o sociálnu alebo zdravotnú odkázanost'.

Libertariánsky systém zdravotnej starostlivosti je trhovo orientovaný, zdravotná starostlivost' je komoditou, ktorú možno nakupovat' a predávat', ponúka sa na trhu na základe princípov ponuky a dopytu. Tovarom je zdravotná starostlivost', ktorá sa poskytuje tým, čo si ju platia v hotovosti, alebo na ňu pravidelne prispievajú prostredníctvom poist'ovacieho systému. Poistenie zdravia má znaky komerčného poistenia a vstupujú doň komerčné poist’ovacie subjekty, ktoré uzatvárajú zmluvy na základe individuálnych podmienok a v prípade porušenia zmluvy majú právo od tejto zmluvy odstúpit'. Výšku poistného odvodzujú od individuálneho ocenenia zdravotného rizika. Štát do tohto typu systému bud' nezasahuje vôbec, alebo len do istej miery. Môže napríklad umožňovat' kumulovat' zdroje od viacerých subjektov - zamestnancov i zamestnávatel'ov, ukladat' poist'ovacím subjektom špecifické podmienky podnikania, zakotvit' v zákonných normách práva a povinnosti profesijných združení a podobne.

Výlučný dôraz na individuálnu autonómiu a osobnú zodpovednost' je však pomerne problematickým východiskom pre tvorbu princípov zdravotnej starostlivosti v štáte Ich akceptácia totiž problematizuje ideu rovnosti príležitostí (Held 2015, 142 a n.), ale aj idey spravodlivosti. Rawls prijíma hodnotu individuálnej autonómie ako ideu, že spravodlivá spoločnost' zaobchádza s l’ud'mi ako s rovnými (Nozick 1977, Rawls 1997) a každý má právo prežit’ život podl'a vlastných predstáv a zvolit' si konkrétnu podobu vlastného života. To vytvára definičný priestor, v ktorom sa musí pohybovat' teória spravodlivosti. (Palovičová 2013, 105). Princíp individuálnej zodpovednosti vyžaduje od vlád, aby zabezpečili, že osudy občanov nebudú závislé od ekonomického základu, rodu, rasy či individuálneho súboru vlastností a znevýhodnení (Dworkin 1981, 286). Je teda nutné, aby boli odlíšené dôsledky, za ktoré jednotlivec nesie či nenesie zodpovednost'. Takéto odlíšenie by sa malo stat' kritériom pri posudzovaní nároku na to, či občan môže alebo nemôže čerpat' prostriedky z verejných zdrojov.

Štát, ktorý preferuje libertariánsky systém zdravotnej starostlivosti nemusí formulovat’ zásady zdravotnej politiky štátu, čo neznamená, že to nerobí. Nič ho nenúti definovat' primárne funkcie zdravotnej starostlivosti, monitorovat' zdravotný stav populácie či investovat' do budovania zdravotníckych zariadení v záujme zabezpečenia dostupnosti zdravotnej starostlivosti. Nemusí sa zaoberat' určovaním štandardných metód a postupov. ${ }^{13}$ Zdravotnícke zariadenia sú totiž väčšinou ziskovými subjektmi, rovnako ako farmaceutické firmy a komerčné poist’ovne. Občan, pacient je klient a zákazník

${ }^{13}$ To sa samozrejme netýka prostriedkov a postupov, pri ktorých sa vyžaduje certifikácia - lieky, zdravotnícka technika či pomôcky -, dodržiavanie určitých normatívnych kritérií, napríklad bezpečnostných i environmentálnych, alebo akreditácia, ako v prípade študijných odborov či práva byt' školiacim zariadením. 
a podl'a toho sa s ním zaobchádza. Má právo regulovat' svoje nákupné správanie a vyberat' si, za akých okolností a akú zdravotnú starostlivost' bude preferovat'. Má možnost' vol'by a nemusí o potrebe zdravotnej starostlivosti do budúcnosti uvažovat' vôbec. Občan sa orientuje na základe ponuky a dopytu a zdravotnú starostlivost' môže uhrádzat' podl'a aktuálnych potrieb.

Ked’že zdravotníctvo je ziskový sektor a tvorba zisku - akokol'vek amorálne to môže v kontexte problematiky poskytovania zdravotnej starostlivosti zniet' - je základným predpokladom d'alšieho skvalitňovania zdravotníckych služieb, ale len ak ho podniky investujú so výskumu a vývoja nových technológií, metodík, liekov a postupov. V libertariánskom modeli sa dôraz kladie na individuálnu zodpovednost' jednotlivca a rodiny za zabezpečenie zdravotnej starostlivosti. ${ }^{14}$ Ak máme pomenovat' nevýhody libertariánskeho systému zdravotnej starostlivosti, tými najvýznamnejšími sú nedostupnost' zdravotnej starostlivosti pre isté skupiny obyvatel'stva v zmysle geografickom alebo sociálnom. Nedostupnost' zdravotnej starostlivosti však možno posudzovat' ako nerovnost'. Keby sme uvažovali podobne ako Rawls (Rawls 1995, 27 - 28), že všetci členovia spoločnosti by mali mat' k dispozícii rovnaké množstvo zdrojov - v Rawlsovom chápaní foriem dobra - potom by v liberálnom systéme zdravotnej starostlivosti nesporne jestvovali nerovnosti a boli by obsiahnuté aj v podstate systému. ${ }^{15}$

Sociálno-liberálny systém zdravotnej starostlivosti funguje v krajinách Európskej únie ${ }^{16}$ a všetci s ním máme nejakú osobnú skúsenost'. Právo na zdravotnú starostlivost' ukotvené v ústavách je zároveň garantovaným právom. Zdravie obyvatel'ov štátu sa pokladá za hodnotu - tak spoločenskú, ako aj individuálnu. Rozsah tohto práva je však

\footnotetext{
${ }^{14}$ Liberálny systém zdravotnej starostlivosti je charakteristický najmä pre USA a rozvojové krajiny. Žial', vo svojej čistej podobe sa objavuje v najchudobnejších krajinách sveta. Z hladiska rozvoja ekonomiky sa za výhodu pokladá to, že systém nezat'ažuje zamestnávatel'ov ani občanov, zamestnancov, povinnými platbami, a ponecháva na ich vôli, ochote či solventnosti, či budú zdravotne poistení alebo nie. Systém je flexibilný a vyznačuje sa vysokou efektivitou práce, prehl’adným systémom financovania, analytickým systémom s následnou tvorbou stratégií zdravotníckych zariadení, funkčným inovačným cyklom, flexibilným zavádzaním nových technológií a vysokou kvalitou poskytovania zdravotníckych služieb. V systéme fungujú motivátory podporujúce osobnú zodpovednost' za zdravie.

${ }^{15} \mathrm{~V}$ intenciách libertariánskeho chápania spravodlivosti sa takýto systém zdravotnej starostlivosti napriek všetkému doteraz uvedenému, pokladá za spravodlivejší, lebo nik nie je nútený platit' za to, pre čo sa sám nerozhodne, pričom to platí pre občanov, ale aj pre zamestnávatel'ov.

${ }^{16}$ V Európskej únii fungujú dva základné modely sociálneho systému zdravotného poistenia: 1) systém jedinej zdravotnej poist'ovne, ktorej aktivity zastrešuje i riadi štát. Tento model je známy napríklad z Vel'kej Británie, Francúzska či Belgicka. Jeho výhodou je možnost' priamej kontroly štátu nad tokmi financií, ktoré plynú do verejného zdravotníctva. Zvyčajne sa označuje aj ako národná poistovacia služba; 2) systém viacerých poist’ovní - zvyčajne v kombinácii štátnych i súkromných zdravotných poist'ovní -, ktoré majú rovnaké podmienky podnikania. Na trhu si navzájom konkurujú a ovplyvňujú systém zdravotnej starostlivosti v krajine. Tento model preferuje väčšina krajín EÚ, funguje v Nemecku, Dánsku, Česku i na Slovensku.
} 
$\mathrm{v}$ rozličných krajinách rôzny, a to $\mathrm{v}$ závislosti od ekonomických možností daného štátu. Zvyčajne sa vníma ako právo na dostupnost' zdravotnej starostlivosti, v niektorých krajinách sveta aj ako právo na bezplatnú zdravotnú starostlivost'. Väčšinou sa otázka dostupnosti zdravotnej starostlivosti interpretuje ako právo pre nemajetných za nich preberá náklady na zdravotnú starostlivost' štát. $V$ zásade je tento typ systému postavený na akceptácii zdravia ako spoločenskej hodnoty. Vzájomná solidarita je princípom spolupatričnosti a podpory bez ohl'adu na individuálne nároky na zdravotnú starostlivost'. Na označenie uvedeného systému zdravotnej starostlivosti sa najčastejšie používajú termíny solidárny alebo sociálno-liberálny. ${ }^{17}$ Hoci sme si vedomí, že nejde o synonymá, obidva termíny slúžia na označenie toho istého. Ak poznáme odpoved' na otázku, aké hodnoty kreovali systém, musíme sa d’alej pýtat', či tie isté hodnoty vstupujú do procesov zdravotnej starostlivosti a či sú aj reálnymi, nie iba formálne deklarovanými hodnotami. Ide o morálne princípy identifikované autormi ako T. L. Beauchamp a J. F. Childress, ktoré sa pokladajú za paradigmatické vyjadrenie podstaty starostlivosti v modernej medicíne. Ide o princípy nonmaleficiencie, benefície, autonómie a spravodlivosti. ${ }^{18}$

Systémy zdravotnej starostlivosti sú previazané s konkrétnymi modelmi sociálneho štátu a historicky s reakciami na rôzne podnety a metodiky riešenia otázok súvisiacich s konkrétnymi výkonmi v rámci zdravotnej starostlivosti, $\mathrm{s}$ otvorenost’ou systému voči novým metódam a metodikám, ako aj možnostiam ich využívania v rámci systému zdravotnej starostlivosti. Sociálny systém zdravotnej starostlivosti vychádza z univerzalistického modelu, kde je poskytovanie starostlivosti vnímané ako sociálne právo, čo sa prejavuje (alebo má prejavovat') vo verejných výdavkoch na zdravotnú starostlivost' (Palovičová 2013, 15). Úlohou systému je, v zásade, zabezpečit' zdravotnú starostlivost' ako verejnú službu každému, kto ju potrebuje. Od výkladu princípu solidarity sa odvíja tvorba legislatívnych noriem v štáte. Štát potom formuluje princípy štátnej zdravotnej politiky, zákonné normy a princípy alokácie verejných zdrojov určených na zdravotnú starostlivost', ako aj kritériá, na základe ktorých je zdravotnú starostlivost' občanom poskytovaná.

Špecifikácia fungovania sociálno-liberálneho systému zdravotnej starostlivosti je daná legislatívnymi normami, tie sú však determinované právom na zdravotnú starostlivost'. Štát zdroje určené na zdravotnú starostlivost’ pokladá za verejné a prostredníctvom zákonných noriem upravuje, ako s nimi možno nakladat'. ${ }^{19}$ Sociálno-liberálny

17 Používajú sa obidva názvy, častejšie sa systém označuje ako sociálny, ked’že solidarita sa pokladá za hodnotu, a nie za pojem, ktorým sa má označovat' systém.

${ }^{18}$ Bližšie k jednotlivým zásadám pozri Beauchamp, T. L., Childress, J. F.: Principles of Biomedical Ethics. New York - Oxford: Oxford University Press 2009.

19 Zdroje sa získavajú od občanov prostredníctvom odvodov z určitého vymeriavacieho základu. Každý pracujúci občan štátu je povinný do systému zdravotného poistenia prispievat', a týka sa to aj 
systém zdravotného poistenia nemá znaky komerčného poist'ovacieho systému a podmienky výkonu zdravotného poistenia sú zvyčajne špecifické. V zásade zdravotné poist'ovníctvo funguje na báze prerozdel'ovania finančných prostriedkov podl'a istého klúčca. ${ }^{20}$ Dostupnost' zdravotnej starostlivosti, monitorovanie a ovplyvňovanie zdravotného stavu populácie sú základnými výhodami tohto systému.

Pri posudzovaní modelu sociálno-liberálneho systému zdravotnej starostlivosti je na prvý pohl'ad zrejmé, že ide o systém v záujme zabezpečenia dobra pre čo najväčší počet l'udí. V zásade to predstavuje spravodlivý, a teda aj rovnaký prístup k zdravotnej starostlivosti. Systém je postavený na utilitaristických kritériách a je v ňom obsiahnutá rovnost' všetkých občanov štátu - každý má mat' z fungovania systému rovnaký úžitok, a aj reálne možnosti využívat' všetky formy zdravotnej starostlivosti, dokonca aj tie, ktoré v štáte neposkytuje žiadne zdravotnícke zariadenie. Zdravotná starostlivost' nemôže byt' komoditou. ${ }^{21} \mathrm{~V}$ systéme rezonujú idey rovnosti a spravodlivosti a systém má a musí poskytnút' rovnaké šance všetkým, a to bez ohl'adu na vek, postavenie, sociálny status, či zdravotné znevýhodnenie. Fungovanie sociálno-liberálneho systému zdravotnej starostlivosti však nevyžaduje motivátory na podporu osobnej zodpovednosti za zdravie. Nezodpovední, l'ahostajní, leniví či takí, ktorí zámerne vyhl’adávajú zdravotné riziká, zo systému profitujú. Zdravotnú starostlivost' môže, a dokonca musí mat' možnost' využívat' aj ten, kto sa systematicky sebapoškodzuje, ${ }^{22}$ o svoje zdravie sa nestará, úmyselne odmieta zdravotnú starostlivost', alebo dokonca ignoruje isté konkrétne úkony, ktoré sú štandardné a dôležité pre vývin alebo zdravie jednotlivca. Podl'a Rawlsa má síce každý jednotlivec právo žit' život podl'a vlastných predstáv (Rawls, 27), ale princíp maximalizácie celkového úžitku pre spoločnost' nemôže byt' pre žiadnu spoločnost' štandardom spravodlivosti. To však vyplýva z nastavenia systému, ktorý vzhl'adom na povinný charakter poistenia - zmluvu o zdravotnom poistení občan musí uzavriet', nemôže ju zrušit' a nevstupuje do procesu tvorby poistných sadzieb - zvýhodňuje tých, ktorí princíp povinnosti, v tomto prípade starostlivosti o vlastné zdravie, ignorujú. Problém sa systematicky

ich zamestnávatel'ov. Štát prispieva zo štátneho rozpočtu na nemajetných, deti, študentov, dôchodcov, nezamestnaných a sociálne odkázané osoby.

${ }^{20} \mathrm{Z}$ morálneho hl'adiska je systém odvodov na zdravotnú starostlivost' vel'mi t’ažké posudzovat'. Solidarita je jedna $\mathrm{z}$ ústredných hodnôt systému a vyplýva z nej prerozdelenie zdrojov podl’a potrieb, nie podl'a toho, kto a akou sumou do systému prispieva. Ako etické východisko je systém prerozdel'ovania budúcich zdrojov na báze rovnosti všetkých l'udí vysoko humánny, služby, zdravotná starostlivost' sú nasmerované k tým, ktorí ich potrebujú.

${ }^{21}$ Morálne normatívne kritériá neumožňujú určovat’ limity na nákup zdravotnej starostlivosti, ani medicínske ani geografické. Dostupnost' zdravotnej starostlivosti je zabezpečená siet'ou zdravotníckych zariadení, ktorú stanovuje štát v rámci štátnej zdravotníckej politiky.

${ }^{22}$ Sebapoškodzovanie má rôznu podobu a formy, najznámejšími sú požívanie alkoholu a drog, fajčenie a iné druhy závislostí atd’. 
riešit' nedá, jedine systémom bonusov a benefitov pre tých, ktorí sa o svoje zdravie starajú, to je však klasický trhový nástroj. Natíska sa otázka, či je štát orgánom kolektívnej zodpovednosti. Nik ho však takto nedefinoval. Zodpovednost' sa vzt'ahuje vždy len na indivíduum alebo konkrétnu právnickú osobu. Preto zodpovednost' za liečbu vždy nesie konkrétna osoba, lekár, ale za manažment pacienta - teda za nadväznost' jednotlivých úkonov a ich kvalitu - je zodpovedné zdravotnícke zariadenie. Zodpovednost' za vlastné zdravie a s tým spojená možnost' prežit' plnohodnotný zdravý život v systéme nefungujú ako determinanty, ale žiadalo by sa, aby nimi boli, inak dochádza k plytvaniu verejnými zdrojmi. Štát je zodpovedný za to, akú kvalitu zdravotnej starostlivosti systém poskytuje, ako systém funguje, kol'ko zdrojov je v ňom a aká je efektivita ich využívania. Problematika kvality zdravotnej starostlivosti zvyčajne priamo závisí od štandardov zdravotnej starostlivosti, stratégie štátnej zdravotnej politiky a financovania systému. Nároky na zdravotnú starostlivost' stále rastú, čo je spôsobené nielen starnutím populácie a chorobnost'ou mladej generácie, ale aj náročnost'ou modernej medicíny na technológie - diagnostiku a liečbu -, a teda na kvalifikovaných l'udí a zdroje. Problematika kvality zdravotnej starostlivosti nie je zanedbatel’ná, lebo úzko súvisí s otázkou ovplyvňovania kvality života ako podmienky lepšieho uplatnenia, možnosti prežit' plnohodnotný život, a teda mat' rovnaké šance. Ovplyvňovanie kvality života sa v súčasnosti pokladá za potrebné a nevyhnutné, ale nie štandardné. Ak totiž jestvujú metódy a postupy na ovplyvnenie kvality života alebo dížky života, je z morálneho hladiska nevyhnutné využit' ich, a zároveň ich zaradit' do systému bez ohl'adu na cenu zákrokov a výkonov. Fungovanie systému však priamo závisí od flexibility štátnych orgánov a administratívnej náročnosti jednotlivých procesov. To, čo na prvý pohl'ad nesúvisí s morálnymi otázkami, má však morálne dôsledky, pretože ovplyvňuje fungovanie systému - dostupnost' modernej liečby a spravodlivé prerozdel'ovanie zdrojov v systéme - teda tie faktory, ktoré stažujú prístup k zdravotnej starostlivosti.

\section{K otázke hodnôt v systémoch zdravotnej starostlivosti}

Ako sme sa pokúsili naznačit', pre každý systém sú kl'účové hodnoty. Treba rozlišovat' tie, ktoré systém kreovali, a tie, ktoré doň boli postupne so zmenami systému implementované. Pripomeňme si, že kl'účovými hodnotami libertariánskeho systému sú individuálna autonómia a osobná zodpovednost'. V systéme platí princíp zodpovednosti, v kontexte zodpovednosti za vlastné zdravie a aj princíp rovnosti, lebo princípy sa vztahujú rovnakou mierou na všetkých jednotlivcov a netýkajú sa tých, ktorí zdravotnú starostlivost' nemôžu alebo nechcú využivat'. Ako hodnota je často prezentovaný aj princíp liberálneho individualizmu. Princípy trhového mechanizmu sú často prezentované ako hodnota či výhoda systému, je však sporné, či je vôbec takýto argument vo filozofickej rovine prípustný. V libertariánskom systéme absentuje vzájomná solidarita a zodpovednost' 
v zmysle kolektívnej zodpovednosti. Nedostupnost' zdravotnej starostlivosti pre tých, ktorí ju potrebujú, ale nemôžu si ju dovolit', je nezaujímavá (Nussbaumová, 112), preto je problémom, ktorý je vzhl'adom na platné spoločenské hodnoty a l’udské práva neriešitel'ný. ${ }^{23}$

Vznik sociálno-liberálneho systému podmienili hodnoty ako spravodlivost', solidarita, zodpovednost', rovnost' a autonómia. Pripomeňme si, že v tomto systéme sa zdravie pokladá za spoločenskú i individuálnu hodnotu, ktorú treba chránit'. Zodpovednost' za vlastné zdravie nesie jednotlivec. Štát deklaruje dostupnost' zdravotnej starostlivosti a zodpovednost' za zdravie občanov. Solidarita je hodnota, ktorá by mala zabezpečit' dostupnost', a princíp rovnosti ako rovnosti príležitostí by mal byt' organickou súčast'ou systému. Solidarita ako hodnota systému sa však javí ako nepostačujúca. Aj vtedy, ked' sú pravidlá nastavené pre všetkých rovnako, je dôležité, či vôbec a v akej kvalite je zdravotná starostlivost' dostupná aj pre nemajetných a znevýhodnených. Ak sa pravidlá poskytovania zdravotnej starostlivosti menia a niektoré úkony sú zo systému vyňaté, iné sú spoplatnené, ekonomicky produktívni a majetní sú vo výhode, pretože môžu vynakladat' dodatočné zdroje na potrebnú liečbu. Systém však diskriminuje tých, ktorí nie sú ekonomicky aktívni, lebo ich prístup ku kvalitnej zdravotnej starostlivosti je obmedzený. Znamená to, že libertariánske prvky sa implementujú do sociálno-liberálneho systému zdravotnej starostlivosti. Identifikátorom je, že medicínske ciele, ktoré boli pri kreovaní systému prioritné, sa dostávajú do úzadia, zatial' čo ekonomické ciele nadobúdajú čoraz väčší význam. Problémy sa vynárajú, ked’ v systéme chýbajú kvalifikovaní pracovníci a zdroje na pokrytie zdravotnej starostlivosti nie sú dostatočné. Následne sa hladajú východiská z aktuálnej situácie. Nástroje sú dva. Prvým je obmedzenie dostupnosti zdravotnej starostlivosti, väčšinou zoštíhl'ovanie siete zdravotníckych zariadení. Dôsledkom je umelé znižovanie nárokov systému bez ohl’adu na potreby obyvatel'ov a postupné eliminovanie ideálu rovnosti všetkých občanov vzhl'adom na dostupnost' zdravotnej starostlivosti. Dôsledkom je, že zo systému sa vytrácajú princípy spravodlivosti a rovnosti.. Druhým nástrojom je spomínaná preferencia ekonomických ciel'ov pred medicínskymi. Deklaruje sa, že systém môže efektívne fungovat', len ak d'alšie zdroje budú vynakladat' občania. Deformácia systému sa prejavuje aj tým, že zdravotná starostlivost' sa stáva tovarom a zdravotné poist'ovne ju nakupujú ako komoditu od poskytovatel'ov zdravotnej starostlivosti, presne ako v libertariánskom systéme, a následne sa určovanie limitov a objemov kontraktov premieta do dostupnosti služieb. ${ }^{24}$ Pomenúvajú sa tie tovary a služby, ktoré sú dostupné z verejných

\footnotetext{
${ }^{23} \mathrm{~V}$ štátoch, ktoré preferujú takýto systém, však dostupnost' zdravotnej starostlivosti pre vybrané skupiny obyvatel'stva zvyčajne suplujú mimovládne organizácie.

${ }^{24}$ Denne je možné vykonat' len tol'ko úkonov, napríklad operácií, kol'ko ich zdravotné poistovne uhradia, hoci by ich zdravotnícke zariadenie a jeho personál dokázali urobit' viac. Nedostatok zdrojov v systéme sa tak prejavuje aj na ohodnotení zamestnancov, ktorí sú limitovaní výkonmi, na ktoré nemajú vplyv.
} 
zdrojov, a za všetky ostatné si pacient pripláca, lebo systém ich kategorizuje ako nadštandardné. ${ }^{25}$ Takýto systém postupne stráca znaky spravodlivosti, a aj solidarity, mení sa jeho základný koncept, upúšt’a sa od základných hodnôt. Solidarita sa stáva deklaratívnou hodnotou. Podnikatel'ské subjekty v systéme sa správajú trhovo a sú nástrojom na usmerňovanie a využívanie finančných tokov. Štát síce rozhoduje o prioritách štátnej zdravotnej politiky, nevytvára však podmienky na to, aby systém efektívne fungoval, a priorizuje ekonomické faktory. Základné argumenty sú prevzaté od M. Nussbaumovej (Nussbaumová, 2007, 89), podl'a ktorej sa prestáva hovorit' o potrebách občanov, zato sa hovorí o reálnych možnostiach (capabilities) systému a prístupoch k rovnosti. V súvislosti s hodnotami treba zdôraznit', že obidva spomínané systémy zdravotnej starostlivosti sú hodnotovo nekompatibilné. Preto tie kroky, ktoré sme spomínali, sociálnoliberálny systém ovplyvňujú hodnotovo, mení sa orientácia systému, ktorý sa začína spreneverovat' vízii, ktorá bola nakoncipovaná pri jeho vzniku. Princípy spravodlivosti by podla Rawlsovej teórie sociálneho liberalizmu mali špecifikovat' „férové“ podmienky racionálnej kooperácie slobodných a rovných bytostí. Ak je systém nastavený tak, aby zaručoval maximalizáciu kolektívnych úžitkov (welfare), nesmie sa opierat' o utilitarizmus, ale o kantovský predpoklad rovnosti a slobody jednotlivcov (Rawls 1995, 128). Princíp rovnosti je fundamentálnym základom uvažovania o spravodlivosti, a to najmä v kontexte tvorby princípov fungovania zdravotníckeho systému. Je však potrebné upozornit', že „obvykle sa rozlišujú tri významy rovnosti. Formálna, čiže rovnost' pred zákonom, rovnost' príležitosti v zmysle rovnakých šancí na získanie relevantných schopností alebo zdrojov dôležitých na sledovanie individuálnych ciel’ov a rovnost' výsledkov, ktorá sa týka hodnotenia, distribúcie verejných statkov a bremien v nejakom časovom okamihu“ (Palovičová 2013, 10). A sociálno-liberálny systém zdravotnej starostlivosti by mal zaručovat' rovnost' vo všetkých troch významoch, a nielen to, mal by garantovat' aj maximalizáciu kolektívnych úžitkov.

\section{Literatúra}

BEAUCHAMP, T. L., CHILDRESS, J. F. (2009): Principles of Biomedical Ethics. New York Oxford: Oxford University Press.

DROZENOVÁ, W. (2011): Etika vědy v České republice. Od historických kořenú k spočasné bioetice. Praha: Filosofia.

DWORKIN, R. (2002): Sovereign Virtue. The Theory and Practice of Equality. Cambridge - London: Harvard University Press.

DWORKIN, R. (1997): Svoboda, rovnost a společenství. In: KIS, J. (ed.): Současná politická filosofie. Praha: Oikoymenh, $273-299$.

\footnotetext{
${ }^{25}$ Za nadštandard sa zvyčajne pokladá komfortnejšie ubytovanie, stravovanie, možnost' ovplyvnit' poradovník na určité zákroky, úkony v rámci kozmetických či doliečovacích procedúr, ale aj moderné liečivá na život ohrozujúce ochorenia.
} 
DWORKIN, R. (1981): What is Equality? Part 2, Equality of Resources. In: Philosophy and Public Affairs. 10 (4).

ESPRING-ANDERSEN, G. (1990): The Three Worlds of Welfare Capitalism. Cambridge: Polity Press.

GALDKIJ, I. a kol. (2003): Management ve zdravotnictví. Brno: Computer Press, 30 - 45.

HELD, V. (2015): Etika péče. Osobní, politická, globální. Praha: Filosofia.

KANT, I. (2004): Základy metafyziky mravú. Praha: Kaligram.

NOZICK, R. (1997): Distribuční spravedlnost. In: Kiss, J. (ed.): Současná politická filosofie. Praha: Oikoymenh, $205-238$.

NUSSBAUM, M. (2007): Frontiers of Justice. Disability, Nationality, Species Membership. Cambridge - Massachusetts - London: The Belknap Press of Harvard University Press.

PALOVIČOVÁ, Z. (2013): Morálne dilemy v sociálnych službách. Bratislava: Infopress.

PALOVIČOVÁ, Z. (2012): K Senovej interpretácii l’udského blaha. Filozofia, 67 (7), 576 - 587.

RAWLS, J. (1997): Politický liberalizmus. Prešov: Slovacontract.

RAWLS, J. (1995): Teorie spravedlnosti. Victoria Publishing: Praha.

SEDOVÁ, T., PALOVIĆOVÁ, Z. (2018): Zdravotné postihnutie v kontexte l'udských práv. Filozofická reflexia. Bratislava: Veda.

SMOLKOVÁ, E.: (2014) Etika v zdravotnictve. Filozofický ústav SAV, Bratislava 2014, 15 - 26.

SZAPUOVÁ, M. (2018): Fakty a hodnoty: K otázke hodnotovej neutrality vedy. Filozofia, 73 (2), $693-706$.

Príspevok vznikol ako súčast' grantového projektu VEGA 1/0132/17 Právo na nezávislý život a začlenenie do spoločnosti osôb s postihnutím z pohl'adu sociálnej a politickej filozofie.

Eva Smolková

Filozofický ústav SAV

Klemensova 19

81364 Bratislava 1,

Slovenská republika

e-mail: smolkovaeva@gmail.com

ORCID ID: https://orcid.org/0000-0003-1450-8692 